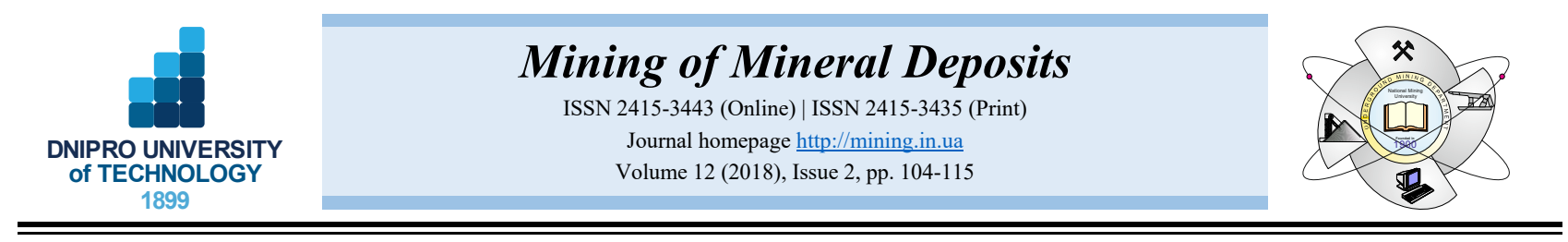

UDC 622.324 .5

https://doi.org/10.15407/mining12.02.104

\title{
THERMODYNAMIC AND GEOMECHANICAL PROCESSES RESEARCH IN THE DEVELOPMENT OF GAS HYDRATE DEPOSITS IN THE CONDITIONS OF THE BLACK SEA
}

\author{
V. Bondarenko ${ }^{1}, \mathrm{~K}_{\text {. Sai }}{ }^{*}$, K. Prokopenko ${ }^{1}$, D. Zhuravlov ${ }^{2}$

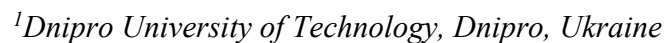 \\ ${ }^{2}$ Scientific Research Institute of Public Law, Kyiv, Ukraine \\ *Corresponding author: e-mail kateryna.sai@gmail.com, tel.+380973966821
}

\begin{abstract}
Purpose. Research of thermodynamic and geomechanical processes occurring in a gas hydrate body under the influence of an activating agent (sea water from surface layers) in the conditions of the Black Sea by mathematical modeling using finite element method.

Methods. The modeling of thermodynamic and geomechanical processes is performed with the use of ANSYS v17.0 software and in accordance with the climatic, hydrogeological and physic-mechanical properties of the numerical model elements in the Black Sea gas hydrate deposit under consideration, which are similar to natural ones. The thermodynamic processes were studied in the section "Steady-State Thermal", and the geomechanical (stress-strain state) in "Static Structural".
\end{abstract}

Findings. The spatial model is developed, which allows to simulate thermodynamic and geomechanical processes in a gas hydrate body under the influence of a thermal agent. As a result of modeling, it was determined that under these conditions the temperature in the gas hydrate body varies with the distance from the production well similarly in both directions according to the polynomial dependence. What is more, at a distance from the well of $18.7 \mathrm{~m}$ the temperature is stable and equals $+22^{\circ} \mathrm{C}$, and in the range of $18.7-24.9 \mathrm{~m}-$ decreases by 3.1 times and reaches a value of $+7^{\circ} \mathrm{C}$. It was found out that deformations in a gas hydrate body under the influence of an activating agent, which is fed under pressure above the initial, are directed from the lateral boundaries to the center of the gas hydrate body in the direction of productive dissociation zones. This, in its turn, results in the displacement of the gas hydrate volume to the reaction proceeding center, improving the quality of the decomposition process and allows mining of $87-91 \%$ gas hydrate volume, which is presented in the model.

Originality. For the first time, for the conditions of the Black Sea gas hydrate deposits, an analytical assessment of the dissociation zone distribution from the production well under the influence of the thermal agent and the changes of the stress-strain state of the gas hydrated body during its decomposition, has been carried out. This allows to improve the technology of the gas hydrate deposits development in the conditions under consideration.

Practical implications. The technological scheme for the development of a gas hydrate body based on the combined approach to the effects of activators (temperature and pressure) is proposed, which eliminates the need to warm the boundary sections of the deposit and increases the amount of the supplied activating agent and its temperatures, which in its turn leads to a decrease in the resource- and energy consumption.

Keywords: gas hydrate deposit, finite element method, ANSYS software package, dissociation zone, technological scheme of development

\section{INTRODUCTION}

In an unstable situation on the Ukrainian gas market, in particular the diversification of hydrocarbon sources, the issue of the prospects determination of state energy security by increasing the volume of own gas production is particularly important. In order to ensure the solution of energy security issues, the Cabinet of Ministers of Ukraine approved the Concept dated December 28, 2016 No.1079 on the development of Ukraine's gas industry, which determines that currently Ukraine is an energy-dependent country. Over the past two decades, natural gas in the country has been mined in almost identical volumes, but in 2013 - 2015 it began to decrease steadily. According to

(C) 2018. V. Bondarenko, K. Sai, K. Prokopenko, D. Zhuravlov. Published by the Dnipro University of Technology on behalf of Mining of Mineral Deposits.

This is an Open Access article distributed under the terms of the Creative Commons Attribution License (http://creativecommons.org/licenses/by/4.0/),

which permits unrestricted reuse, distribution, and reproduction in any medium, provided the original work is properly cited. 
the statistics of the Ministry of Energy and Coal Industry, in 2015, natural gas was extracted in the amount of 19.9 billion $\mathrm{m}^{3}$, which is by $3 \%$ less than in $2014(20.5$ billion $\mathrm{m}^{3}$ ) and by $7.2 \%$ less than in $2013\left(21.4\right.$ billion $\left.\mathrm{m}^{3}\right)$. At the same time, the share of imported natural gas remains high in the country's gas balance, exceeding $40 \%$ of its total needs, which is 33.8 billion $\mathrm{m}^{3}$ by the end of 2015 .

The development of the Ukrainian gas industry with account of the leading foreign countries experience, as well as the latest developments of Ukrainian scientists, can eventually solve the issue of Ukraine's energy security because geotechnological aspects of primary energy resources development in Ukraine and Ukrainian crisis have a negative influence on the mining industry (Petlovanyi, Lozynskyi, Saik, \& Sai, 2018).

Due to rising oil and gas prices, the use of alternative fuels is becoming increasingly urgent. The most commercially prepared energy carrier, capable of replacing petroleum products, is methane. In addition to shale gas, methane of coal deposits, sandstone gas, gas condensate and other hydrocarbon raw materials (Bondarenko, Kharin, Antoshchenko, \& Gasyuk, 2013; Mykhailov, 2016), which are deposited in non-traditional collectors, the gas hydrated deposits are of great importance (Kvenvolden, 1993; Ersland \& Graue 2010; Wang \& Economides, 2011). It should be noted the research aimed at the development and implementation of technologies for obtaining gas as an additional energy source by underground coal gasification in complex mining and geological conditions (Lozynskyi, Saik, Petlovanyi, Sai, \& Malanchuk, 2018), when working out the formation of coal seams (Dychkovskyi et al., 2018) and in the process of biomass gasification (Bondarenko, Lozynskyi, Sai, \& Anikushyna, 2015). Particular attention should be paid to studies on the transfer of coal deposits methane to a gas hydrate state with the purpose of its transporting in the solid state and using as an alternative energy source (Ganushevych, Sai, \& Korotkova, 2014; Taheri, Shabani, Nazari, \& Mehdizaheh, 2014; Bondarenko, Sivetkin, \& Sai, 2017; Chernov et al., 2017).

Gas hydrates are ice-like crystalline compounds that consist of water and natural gas molecules. These are the socalled inclusion compounds: the water molecules bind each other with hydrogen bonds and form the frames with large cavities inside. Chemical bonds between molecules of gas and water are not formed, the molecules are retained only by weak intermolecular Van der Waals forces (Carroll, 2014).

The gas hydrates properties are unique. One volume of water, when converted to a hydrate state, binds up to 200 volumes of methane. At the same time, its specific volume increases by $26 \%$ (when freezing water its specific volume increases only by $9 \%$ ). $1 \mathrm{~m}^{3}$ of methane hydrate at a pressure of $2.63 \mathrm{MPa}$ and temperature of $0^{\circ} \mathrm{C}$ contains 164 volumes of gas. At the same time, the share of gas accounts for $0.2 \mathrm{~m}^{3}$, water $-0.8 \mathrm{~m}^{3}$ (Boswell, 2009).

In nature, gas hydrates are formed in the deep-sea sediments of the seas and oceans and in areas of permafrost - mainly from hydrocarbon gases. The most common gas contained in gas hydrates is methane. In addition to methane, natural gas hydrates may include other hydrocarbons (ethane, propane, butane), as well as carbonic and sulfur gases, hydrogen sulfide, argon, and others (Makogon, 2010a).
The volumes of fuel in the form of gas hydrates (basically methane) exceed the amount of carbon fuel in all its other types on the planet. The distribution of organic carbon on the Earth, with the exception of scattered in rocks and sediments, is shown in Figure 1. It should be noted that more than half of the carbon is in gas hydrates (National Energy Technology Laboratory, 2017).

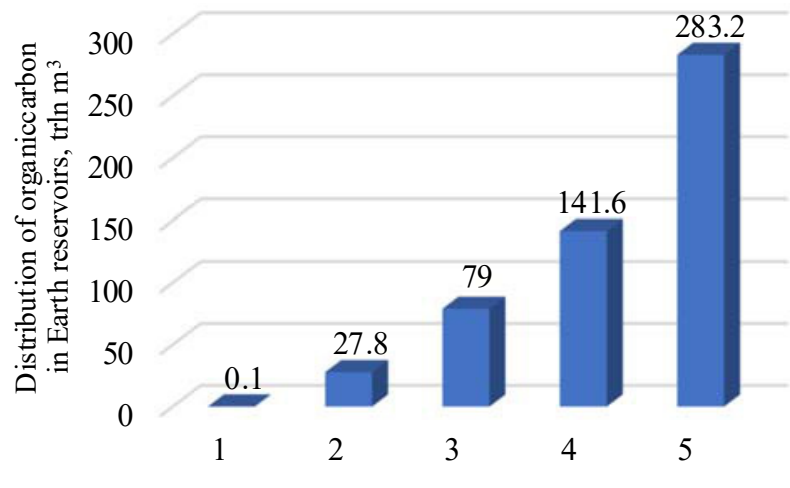

Figure 1. The distribution of organic carbon on the Earth: 1 -in the atmosphere; 2 -in the ocean (including scattered organic and biota); 3 - on land (including soil, biota, peat and detritus); 4 -in fossil fuels; 5 - in gas hydrates

At present, the USA, England, Japan, China, Germany, Norway, Russia and others are engaged in the development of technologies of gas hydrates production. Thus, the US Congress has allocated several billion dollars from the federal budget for the development of gas hydrates in by thermal way. In Japan, one of the largest priority national programs in the world with budget financing has begun work, aimed at the development of marine gas hydrate deposits of the Nankai Depression from a depth of $950 \mathrm{~m}$.

Of great interest are the works of scientists of the Institute of Inorganic Chemistry of the Russian Academy of Sciences on the theoretical study of the hydrates properties, the methods of gas hydrates extraction developed by scientists at I.M. Gubkin University of Oil and Gas, the results of the US Geological Survey and the Japanese oil exploration company Mitsui Engineering \& Shipbuilding. The analysis of methane extraction capabilities in Ukraine, in particular in the Black Sea, is being carried out by scientists at the Marine Hydrophysical Institute of the National Academy of Sciences of Ukraine and the Odessa Academy of Colds. Special attention is deserved by the works of scientists of the State Higher Educational Institution "National Mining University", Ivano-Frankivsk National Technical University of Oil and Gas, Yuri Kondratyuk Poltava National Technical University, S.I. Subbotin Institute of Geophysics of the National Academy of Sciences of Ukraine and the Institute of Gas of the National Academy of Sciences of Ukraine.

Taking into account the urgency and importance of research in the gas hydrate direction, as well as the existing significant energy potential of gas hydrates (Makogon, Holditch, \& Makogon, 2007), evident is the development of technology for gas extraction from gas hydrate deposits and determination of its basic parameters, which will enable Ukraine to provide its own hydrate gas (Bondarenko, Ganushevych, \& Sai, 2012; Bondarenko, Maksymova, Ganushevych, \& Sai, 2013). 


\section{ANALYSIS OF EXISTING METHODS FOR THE GAS HYDRATE DEPOSITS DEVELOPMENT}

In many countries of the world for today, the programs and research centers are created for the study of gas hydrates, since the production of hydrate gas will help to solve the world's energy problems. However, it is extremely important to create and apply techniques and technologies for the gas hydrate deposits development and methane gas production. Technologies of the gas hydrate deposits development are related to the physical and chemical properties of these clathrate compounds and relies on dissociation, due to which gas hydrates separate into gas and water. Releasing the gas contained in hydrates can be achieved by shifting the equilibrium parameters of their stable existence (Maksymova, 2015).

Methods of the gas hydrate deposits development are based on the laws of the gas hydrates existence and their properties. First, it is taken into account that all reserves are located mainly in the depth zones. Secondly, gas hydrates exist under conditions of relatively high pressure and low temperatures (Ganushevych \& Sai, 2013). Water molecules are joined by a hydrogen bond, which is decayed easily with decrease in pressure and rise in temperature. The modern methods of extracting gas from gas hydrates are based on these main characteristics.

There are three main methods for producing gas from gas hydrates (Fig. 2) (Processes for Methane Production..., 2010; Bondarenko, Ganushevych, Sai, \& Tyshchenko, 2011; Rogers 2015; Swaranjit Singh, 2015):

- thermal method based on the heating of the deposit;

- depressive method, which consists in reducing the pressure in the gas hydrate;

- a method of substitution or addition of chemicals that are catalysts of the dissociation process of a gas hydrate deposit. (a)

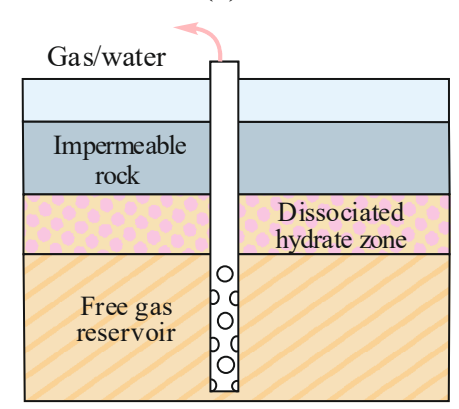

(b)

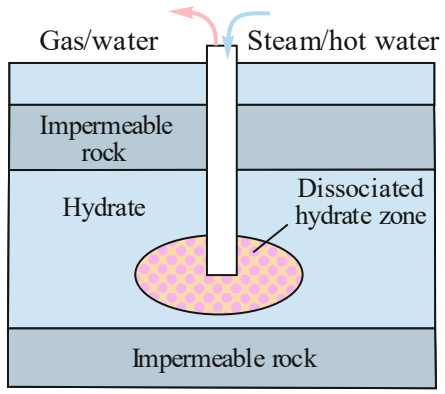

(c)

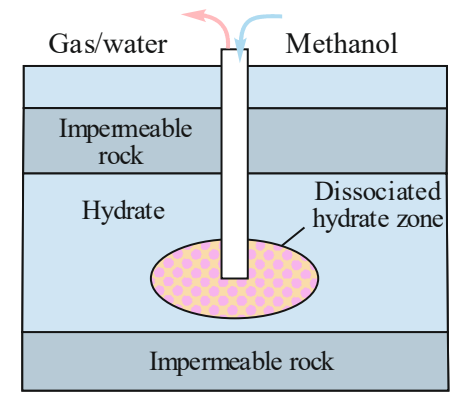

Figure 2. Methods for developing gas hydrate deposits and extracting natural gas from them: (a) depressurization; (b) thermal injection; (c) inhibitor injection (Makogon, 1997; Kollett, L'yuis, \& Uchida, 2001; Ersland \& Graue, 2010)

The essence of the thermal method is based on the supply of heat inside the crystal lattice of gas hydrates in order to increase the temperature and start the process of dissociation by pumping the coolant into the gas hydrate deposit. As a coolant, warm sea water or steam can be used. The coolant is pumped into the gas hydrate layer through the central injection well and the gas, released out from the production well, is collected on the surface. The method of thermal heating has several subtypes. Briefly review the main ones.

Method of heating by a coolant injection. As a rule, water is as a coolant. The efficiency of the technology increases with the supply of hot water in a closed cycle through special pipes. In this case, the open injection of warm water is effective only for gas hydrate strata with thickness of $15 \mathrm{~m}$. In the other case, the loss of heat at the open injection of the coolant may appear excessively large.

Method of hot water circulation. This technological solution was applied to 5-day trial gas production at the Canadian Mallik Field in 2002. During the experiment, water at a temperature of $+80^{\circ} \mathrm{C}$ was pumped into the well with a depth of $1100 \mathrm{~m}$. When the water reached the bottom of the well, the water temperature was $+50^{\circ} \mathrm{C}$. As a result of the technology application, $470 \mathrm{~m}^{3}$ of methane gas was extracted.

The method of gas hydrates decomposition with the use of steam, heated gas or liquid. The method is based on the use of a device, placed next to a gas hydrate deposit or directly into the deposit itself, which allows it be heated with gas or liquid (preferably by steam). Gas hydrate may be heated by direct contact with gas or liquid, or indirectly by the use of a thermally-conductive coil or a channel.

The thermal method for the gas hydrate deposits development can be used for strata with high content of hydrates with a small share of rocks inclusions. When applying this method, it is necessary to take into account the total energy consumption for dissociation of crystalline hydrates and the amount of energy that can be obtained from the extracted gas.

The depressive method of gas extraction from gas hydrate deposits (depressurization) consists in artificially lowering the pressure in the formation around the well below the equilibrium level, which is achieved by the pressure reduce in the drill-hole or by reducing the pressure of water or free gas on the gas hydrate after they are partially pumped out. When the pressure in the gas layer is lower than the phase equilibrium of gas hydrates, the latter one begins to dissociate into gas and water, while absorbing the thermal energy of the ambient medium.

The method of the pressure reduce is suitable for gas hydrate layers, in which the saturation of hydrates is low, and gas or water have not lost their mobility. The technology is most effective when gas hydrates are located near the free gas formation. When the volume of free gas decreases, there is a constant change in the equilibrium between hydrate and gas, which causes the gas hydrate 
continues to emit a gas that fills the lower layer. It is naturally, that with an increase in hydrate-saturation, the efficiency of this method decreases. The main disadvantage of the pressure reduce method is the formation of gas hydrates in the borehole zone, which complicates the gas extraction process.

The method of substitution or addition of chemicals is based on a shift in the phase equilibrium of gas hydrate, which leads to its decomposition. The substitution is to displace methane from the 'cells' of the clathrates by filling them with another gas, such as carbon dioxide. Methanol, glycol, ethanol, saline solutions, etc., can be used as chemical substances used in the development of gas hydrate deposits. There are several subtypes of this method.

Supply of hot supersaturated solutions of calcium chloride or bromide, or their mixtures under pressure down the well. At the same time, water that has separated from the gas hydrate is absorbed by salts with the release of heat.

Method of chemical reagents interaction, which includes the following stages:

1) an exothermic chemical reaction of liquid acid and liquid alkali, which results in the formation of a hot saline solution;

2) contact of a gas hydrate with a hot saline solution and dissociation of the part of the gas hydrate deposit;

3) lifting of the formed water-gas mixture up the well;

4) separation of natural gas from the saline solution on the surface.

Method of substitution by carbon dioxide is to replace the gas molecules of methane, which is the main component of the gas hydrate deposits, by the carbon dioxide molecules. Carbon dioxide can substitute methane in gas hydrate without the formation of excess water, and while releasing methane.

These methods of gas extraction from gas hydrates deposits serve as a base for a lot of variants of gas hydrate deposits development which are offered today. However, all gas extraction technologies require additional both theoretical and experimental research directly within each specific gas hydrate deposit (Maksymova, 2015).

\section{THERMODYNAMIC AND GEOMECHANICAL PROCESSES MODELING AT DISSOCIATION OF GAS HYDRATE DEPOSITS}

\subsection{Mining-geological features of gas hydrate deposits occurrence in the Black Sea}

Research of the conditions of formation, the stable existence and properties of gas hydrates in the natural environment allow us to confidently predict their availability in different regions of the land, the World Ocean, and in particular, in the Black Sea. The Black Sea aquifer is characterized by the presence of gas hydrate deposits, which thickness, according to geologists and seismic survey results, reaches an average of $700 \mathrm{~m}$. The Ukrainian part of the sea has methane gas resources, which can be extracted from gas hydrate deposits located directly opposite the Crimean Peninsula, about $20-25$ trillion $\mathrm{m}^{3}$. The total forecasted gas resources throughout the Black Sea amount at least to 100 trillion $\mathrm{m}^{3}$, based on the results of drilling and analysis of the studied cores (1988-1989)
(Korsakov, Byakov, \& Stupak, 1989; Gas Hydrates in the Black Sea Basin, 1990).

When using oil and gas minerals within the territorial waters and the exclusive (maritime) economic zone of Ukraine, there are certain features of the administrative and legal regulation of special permits for such use. Thus, in compliance with Article 22 of the Law of Ukraine "On Oil and Gas" No.2665-III of July 12, 2001, in the areas of oil and gas bearing deposits located within the territorial waters and the exclusive (maritime) economic zone of Ukraine and for the use of which a special permit has been obtained, the works is carried out in accordance with a special regime established by the owner of the special permit in agreement with the central executive authorities that ensures implementation of the state policy in the areas of the state border and Ukrainian sovereign rights protection in its exclusive (maritime) economic zone, maritime and river transport safety, fisheries, and the central executive body, which ensures the formation and implementation of state policy in the field of environmental protection. The granting for use of oil and gas bearing resources within the exclusive (maritime) economic zone of Ukraine is carried out with account of the legal regime of maritime areas.

The Black Sea is one of the largest and deepest seas. The average depth of the sea is $1300 \mathrm{~m}$. The maximum depth, according to various sources, based on the echo sounding data, is in the range of $2210-2258 \mathrm{~m}$. River water flows entering the sea have a limited flow through the narrow Bosphorus Strait with a depth of $32 \mathrm{~m}$ and a width of about $750 \mathrm{~m}$. The mixing of water is determined only by winds to shallow depths and low-power sips located at depths of up to $700 \mathrm{~m}$.

The modern Black Sea basin is part of the large Alpine orogenic belt. It is the northeastern segment of the Mediterranean mobile zone. In the north, these two depressions border on the southern edge of the Eastern European platform, in the east - with the zone of the Taman dome structures, is the western extension of the Caucasian orogen, in the south - with the Anatolian folded structures, in the west - with the Misei plate and Dobrudja mining structures (Kobolev, 2017).

The north-western part of the Black Sea water area is a tectonic depression (depression) of the Northern Black Sea coast, which arose in the late Maykop period between Dobruja in the west and the Crimean Peninsula in the east. In the south, the depression opens towards the large Black Sea trough, and in the north it embedded deeply into the boundaries of the East European platform.

In the Black Sea area, three main geomorphological elements are distinguished at the bottom: the shelf, mainland slope and deep-water depression. The Black Sea shelf is a coastal part of the seabed to the depths of $90-110 \mathrm{~m}$. The geological structures of the shelf are an extension of land structures. The shelf, or continental shelf, covers $25 \%$ of the sea water area. The continental slope corresponds to a narrow zone of steep bending of the seabed from the outer shelf to the depths of $1830 \mathrm{~m}$ and occupies about $40 \%$ of the water area. The deep-water depression of the Black Sea (about $35 \%$ of the water area) is a flat accumulative plain, which extends from the west to the east in an oval form, slightly inclined to the south. Its bottom is practically even, characterized by low-hill relief, the slope 
angles vary in the range from 0 to $1^{\circ}$. Large forms of underwater relief based on echometric surveys were not found here. The depth is everywhere more than $2000 \mathrm{~m}$.

The existing technologies for the gas hydrate deposits detection are based on the use of the properties of hydrates and hydrate-saturated rocks. These properties are high electrical resistance and acoustic conductivity, reduced permeability for water and gas, thermal conductivity and density. The detection of gas hydrate deposits can be made by seismic or acoustic sounding, gravimetric method, measurement of thermal and diffusion fluxes over the deposit, studying the dynamics of the electromagnetic field in the studied region, etc. (Bondarenko, Maksymova, \& Koval, 2013). The most common method is the standard and high-frequency seismic, according to which, in the occurrence of free gas under the hydrate-saturated strata, the position of the lower boundary of hydrate-saturated is determined - the BSR (Bottom Simulation Reflector) limit (Thakur \& Rajput, 2010).

The analysis of thermobaric conditions within the deep-water part of the Black Sea basin gives all grounds to assert that the available temperature and pressure parameters at sea depths of $500-750 \mathrm{~m}$ are optimal for the formation of gas hydrate deposits in such conditions (97/01843 Thermodynamic Conditions..., 1997; Demirbas, 2009; Shnyukov, 2013). The lower boundary of these deposits existence is $400-500 \mathrm{~m}$ below the seabed and depends on the depth of the sea. Figure 3 shows the thickness of the gas hydrate deposits formation to the south of the Crimean Peninsula.

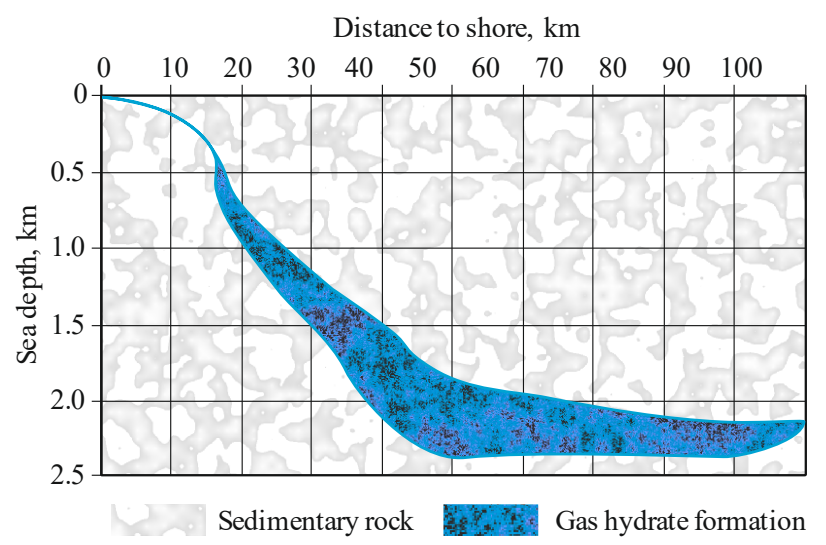

Figure 3. The zone of gas hydrates formation in the Black Sea (Makogon, 2010b)

The accumulated factual data on the extent of the Black Sea degassing and the place of gas hydrate deposits distribution confirms the expediency of complex studies conducting to introduce technologies for the practical extraction of gas from gas hydrates for the needs of the Ukrainian economy and increase in the energy independence of the state (Bondarenko, Maksymova, Ganushevych, Sai, \& Illiashov, 2013; Pedchenko \& Pedchenko, 2017).

\subsection{Methodology and setting the research tasks}

The actual issues in the determination of thermodynamic and geomechanical processes can be solved by modeling, since conducting field experiments is difficult due to the large size of the gas hydrate deposit and, as a consequence, substantial costs for carrying out the experiment.
To solve the engineering problems in the mineral deposits development, mathematical modeling based on the finite element method for solid minerals has become widely used (Bondarenko, Symanovych, \& Koval, 2012; Lan, Hou, \& Fan, 2015) as well as minerals that change their aggregate state in the process of extraction (Kimoto, Oka, Fushita, \& Fujiwaki, 2007; Zhao et al., 2013). One of the most well-known software packages based on the finite element method is ANSYS, which meets the needs for calculating the thermodynamic and thermobaric conditions of gas hydrates dissociation. As a CAD system, the "COMPAS 3D v17.1" package is used, since the created graphical objects can be transferred directly to ANSYS.

In order to achieve this goal, the research is carried out in two stages. The first step is to conduct a temperature analysis taking into account the properties of the selected materials and their interaction. The second stage of research is the assessment of pressure effect of the activating agent supplied (water from the surface layers of the Black Sea) on the gas hydrate body and its deformation.

The development of a gas hydrate body was modeled for the conditions of the second geomorphological element of the Black Sea - the continental slope - at a depth of $700 \mathrm{~m}$, where the initial pressure in the gas hydrate deposit is $7 \mathrm{MPa}$. In this zone, the gas hydrate body has sufficient thickness, suitable for industrial development. The dimensions of the initial model were taken by experimental selection (alternative parameters led to more complicated calculations, and also had low accuracy in the final analysis due to the fact that the finite element mesh had a small number of finite elements and their large sizes, and the creation of a model with smaller dimensions is irrelevant, since the size of the gas hydrate deposit is quite significant) and were $50 \times 50 \times 75 \mathrm{~m}$.

The simulated object consists of three parts:

- the enclosing roof and bottom rocks (the thickness of the roof is $25 \mathrm{~m}$, the bottom $-30 \mathrm{~m}$ ) are represented by sandstone (since $87 \%$ of the explored deposits were found in such rocks);

- gas hydrate body with a thickness of $20 \mathrm{~m}$ (in natural conditions, the gas hydrate deposit is characterized by fluctuations in thickness, but, with the purpose to simplify the calculations, a formation with constant thickness is considered);

- production well with a diameter of $0.4 \mathrm{~m}$ (since this will be enough for placement of equipment and technical means) and a depth of $40 \mathrm{~m}$ (taking into account the roof rocks thickness and $2 / 3$ of the gas hydrate body thickness, that is conditioned by the gas hydrate deposit processing scheme).

The well is represented in the model as a simulated solid body, and the effect of the activating agent pressure on the decomposition process is directed towards the gas hydrate body. To create a pressure difference (agent and gas hydrate body), sea water is supplied at a pressure of $8 \mathrm{MPa}$, which exceeds the existing equilibrium pressure in the gas hydrate deposit.

Table 1 shows the basic physical and mechanical properties of the simulated object, which includes the rock, gas hydrate and water used in the modeling process. 
Table 1. Physical and mechanical properties of structural elements in the gas hydrate deposits development

\begin{tabular}{lccc}
\hline \multicolumn{1}{c}{ Parameter } & $\begin{array}{c}\text { Rocks of roof } \\
\text { and bottom }\end{array}$ & $\begin{array}{c}\text { Gas hy- } \\
\text { drate body }\end{array}$ & Water \\
\hline Density, $\mathrm{t} / \mathrm{m}^{3}$ & 2.4 & 0.9 & 1.03 \\
Young's module, $\mathrm{MPa}$ & 0.018 & 0.1 & $2000^{*}$ \\
Poison's ratio & 0.32 & 0.42 & $0.5^{* *}$ \\
Thermal conductivity, & 1.8 & $3.8^{* * *}$ & 0.6 \\
$\mathrm{~W} / \mathrm{mm} \cdot \mathrm{K}$ & & & \\
\hline
\end{tabular}

*Vilner, Kovalev, \& Nekrasov, 1976

${ }^{* *}$ Krevelen \& Nijenhuis, 2009

${ }^{* * *}$ Waite, Stern, Kirby, Winters, \& Mason, 2007; Permyakov, 2010

Gas hydrate as an initial form of ice has abnormal heat capacity, specific heat of melting, and dielectric permittivity. The phase transition forms shields of different types and scales from gas hydrates stored in permafrost to ice sheets (Melnikov, \& Gennadinik, 2018).

Guided by the fact that the physical properties of the gas hydrate as a solid body are similar to ice, the physicalmechanical parameters of the gas hydrate body, shown in the table, were considered equivalent to ice. As an activating agent we use seawater as it is very safe for the environment, and also is available in an excess near the marine gas hydrate deposits. For water, there is no Poisson's ratio, since it is an incompressible fluid, in accordance with the basic Archimedes laws, Euler and New-Stokes equations. Therefore, an alternative parameter is a volume elasticity modulus, equal to $2000 \mathrm{MPa}$ for water. In the calculation we accept this value.

The water temperature of the surface layers of the Black Sea is $+18 \ldots+24^{\circ} \mathrm{C}$, based on this, we accept the temperature of the activating agent $+22^{\circ} \mathrm{C}$. In winter it is necessary to heat the water to the desired temperature. The temperature of the hydrate is accepted to be $+4^{\circ} \mathrm{C}$, since according to the research center "MARUM" (Germany) data, the temperature of the deposit is $+3 \ldots+6^{\circ} \mathrm{C}$. For roof and bottom rocks of the deposit, the temperature is accepted to be $+18^{\circ} \mathrm{C}$, based on the data of the Institute of Geological Sciences of the NAS of Ukraine. The heat exchange processes that are of interest to us, occurring between the gas hydrate and the activating agent, respectively, if to isolate the water, which is supplied in the well, then the heat exchange between the rocks can be neglected. Since water is present in both the gas hydrate and as the activating agent, it is possible to assume that forced convection occurs precisely with water, therefore, the convection coefficient can be accepted as equal to $600 \mathrm{~W} / \mathrm{mm}^{2}$. To control the dissociation process, we set the time of influence as equal to 20 hours. This value is chosen based on the experience of foreign research at the Nankai (Japan) (MH21 Research Consortium, 2018) and Mallik (Canada) deposits (JOG-MEC/NRCan/Aurora, 2018)). The minimum flux value is $100 \mathrm{~W} / \mathrm{mm}^{2}$, and the maximum is $200 \mathrm{~W} / \mathrm{mm}^{2}$.

The first stage of the research is to conduct a temperature analysis taking into account the properties of the selected materials and their interaction. The most important parameter is the thermal conductivity, but for gas hydrates there is no constant value. According to Permyakov (2010), as well as British and American scientists (Waite, Stern, Kirby, Winters, \& Mason, 2007) the certain values of thermal diffraction at different gas temperatures have been established.
The second stage is an assessment of the effect of pressure, under which the water is injected through the well, onto the gas hydrate deposit, and its deformation. For this purpose, a similar model is used, but the initial conditions are changed and some properties of the materials are added. Since, action of the activating agent on the hydrate is of scientific interest only, a rigid fixation of the roof, bottom and well is established.

The result of the research is to obtain curves of thermal analysis and static stresses, which are further analyzed.

\subsection{Analysis of modeling results}

Using the ANSYS program "Steady-State Thermal", the thermal analysis of the created model was performed taking into account the given physical and mechanical, as well as thermodynamic properties of the model elements, a thermal effect curve was obtained (Fig. 4a).

(a)

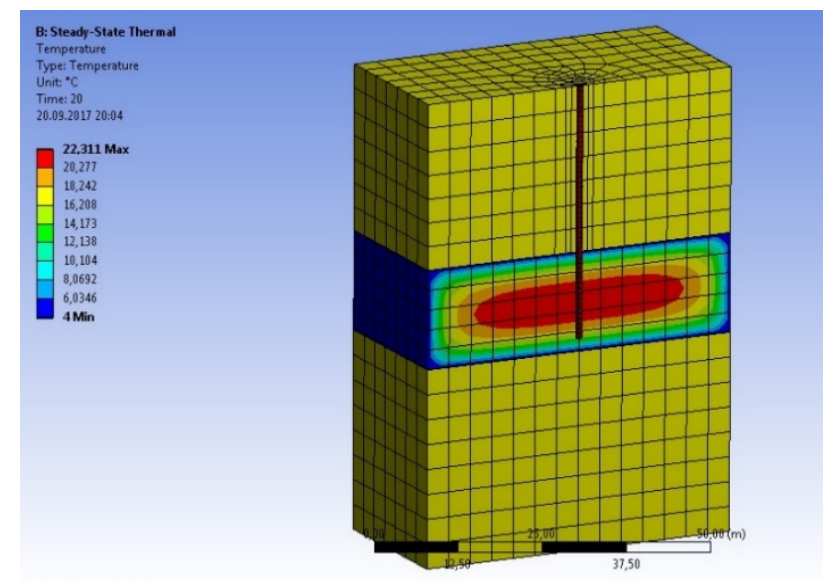

(b)

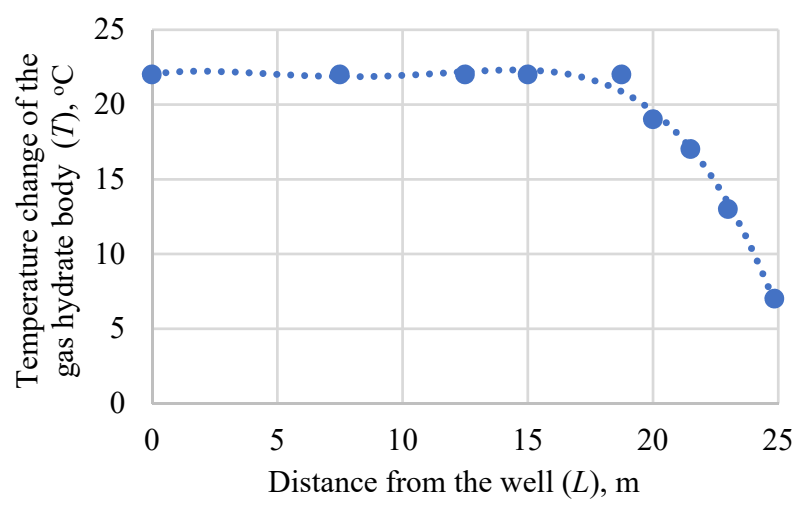

Figure 4. Results of the thermal analysis of the model: (a) the curve of thermal effect on the gas hydrate body; (b) the dependence of temperature change of the gas hydrate body with an increase in distance from the well

It is established that the maximum destructive effect acts around the well and decreases toward the deposit boundary in the model. The analysis of the curve shows that under given conditions in the model, the temperature in the gas hydrate body varies with the distance from the injection well similarly in both directions according to the polynomial dependence of the form $T=-0.003 L^{4}+0.0087 L^{3}-0.0856 L^{2}+0.2439 L+22.016$ 
at $R^{2}=0.99$ (Fig. 4b), and at a distance from the well of $18.7 \mathrm{~m}$ the temperature is stable and is $+22^{\circ} \mathrm{C}$, and in the range of $18.7-24.9 \mathrm{~m}$ it decreases by 3.1 times and reaches a value of $+7^{\circ} \mathrm{C}$. As can be seen from the curve, the nature of the thermal effect extends through the thoroid and leads to qualitative destruction only within the limits of this figure (diameter $37.5 \mathrm{~m}$ ), but for the productive work, destruction of the remaining gas hydrates is also necessary.

For this purpose, it is necessary to conduct a study of the gas hydrate body model on static stresses under the effect of an activating agent, which is fed through the borehole at a pressure of $8 \mathrm{MPa}$, which exceeds the initial pressure in the gas hydrate equal to $7 \mathrm{MPa}$, formed at the considered depth.

Using the ANSYS program subdivision "Static Structural", a static analysis of the stress-strain state of the created model was performed, under the effect of a thermal agent, fed with pressure higher than the initial value in the gas hydrate body (Fig. 5).

(a)

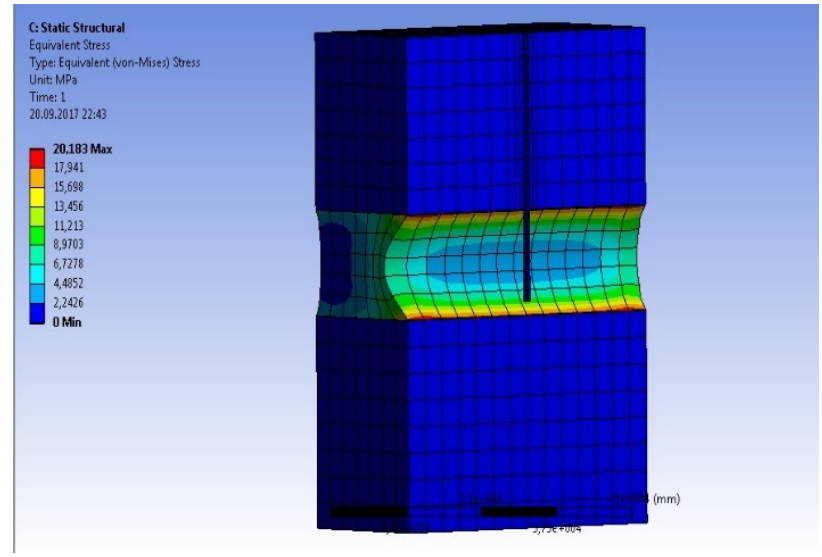

(b)

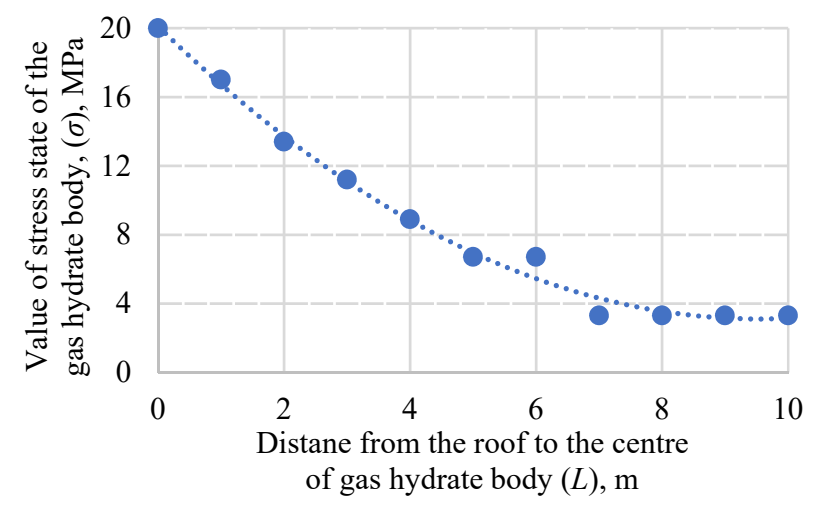

Figure 5. Results of the stress state study of the gas hydrate body: (a) a curve of equivalent stresses; (b) the dependence of the stresses change according the gas hydrate body thickness

Based on the obtained results of the stresses curve study (Fig. 5a), it can be stated that in view of the gas hydrate body thickness, the maximum pressure is formed on its contact with the enclosing rocks of the roof and the bottom, and is $20 \mathrm{MPa}$, and the minimum pressure - in a diameter $37.5 \mathrm{~m}$ around the well with a value of $3.3 \mathrm{MPa}$.
Accordingly, this indicates that the gas hydrate decomposition reaction occurs with high-performance in the area of a spheroid with a diameter of $37.5 \mathrm{~m}$, since the pressure value within this figure is lower compared with the initial equilibrium pressure in the deposit. However, the problem of influence within the gas hydrate deposit boundaries is still unresolved.

The pattern of the stresses field distribution by the thickness of gas hydrate body and in accordance with the curve, indicates that the stresses in the gas hydrate body vary rather uniformly from its roof and from its bottom to the center according the polynomial dependence of the form $\sigma=0.18 L^{2}-3.56 L+20.11$ at $R^{2}=0.99$ (Fig. 5b). At a distance of $6 \mathrm{~m}$ from the roof and the bottom, the pressure is reduced by 5 times from 20 to $4 \mathrm{MPa}$, then it slightly decreases and reaches a minimum value of 3.3 $\mathrm{MPa}$, and it remains constant in the gas hydrate body center. Along the length of the gas hydrate body from the production well, the stress state varies slightly from 3.3 to $6.5 \mathrm{MPa}$.

For more meaningful conclusions on the determination of the productive zone of the gas hydrate body dissociation, a curve of its deformations under the influence of temperature and pressure of the activating agent, was obtained (Fig. 6a). The analysis of the deformation curve of the model allows to state that maximum deformations are observed at the lateral boundaries of the hydrate deposit and are $10-11 \mathrm{~m}$ and decrease toward its center to $7-8 \mathrm{~m}$ in accordance with the polynomial dependence of the form $U=-0.0004 L^{3}+0.02 L^{2}-0.53 L+11.09$ at $R^{2}=0.97$ (Fig. 6b). While the minimum deformations are observed on the contact of a hydrate body and the enclosing rocks with a value of 1 to $2 \mathrm{~m}$ and increase to $8 \mathrm{~m}$ in the center in accordance with the polynomial dependence of the form $U=-0.08 L^{2}+1.59 L+0.52$ at $R^{2}=0.96$ (Fig. 6c).

Deformations are directed from the lateral boundaries to the center of the gas hydrate body, which in turn leads to the displacement of the gas hydrate volume into the center of its decomposition reaction.

Based on the obtained modeling data, one can state the following: the qualitative dissociation zone under the influence of temperature is limited by the volume of the thoroid with a diameter of $37.5 \mathrm{~m}$, and the productive effect of pressure is within the range of a spheroid with a similar diameter of $37.5 \mathrm{~m}$. Thus, the quality of dissociation increases, which makes it possible to mine $87-91 \%$ of the gas hydrate body presented in the model.

The solution of the problem of mining the boundary areas of the deposit on the contact with the enclosing rocks is that under the influence of temperature and pressure there are deformations, which shift the boundary areas of the deposit by $10-11 \mathrm{~m}$ in the direction of productive zones of dissociation.

The complex approach to the temperature and pressure effect on the deposit is quite effective and promising, since, operating the data from the conducted studies for a given volume of a gas hydrate body, it is possible to minimize the costs of the fed activating agent, as there is no need to increase the amount of agent and its temperature for heating the boundary areas of the deposit, which, in turn, leads to a decrease in resource and energy costs. 
(a)

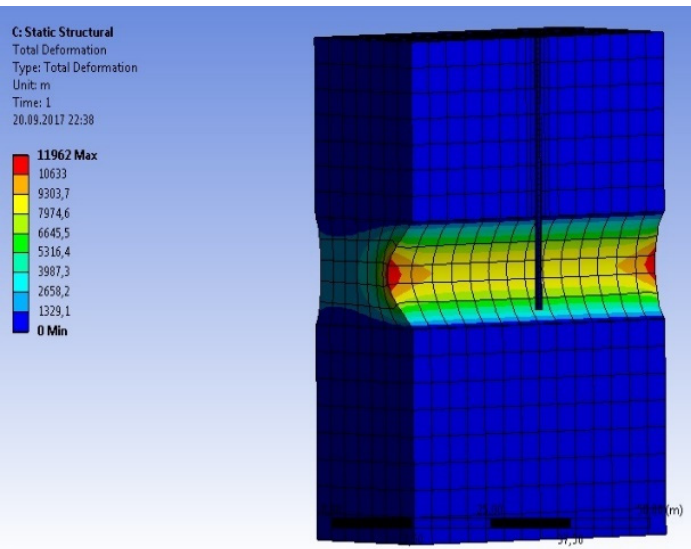

(b)

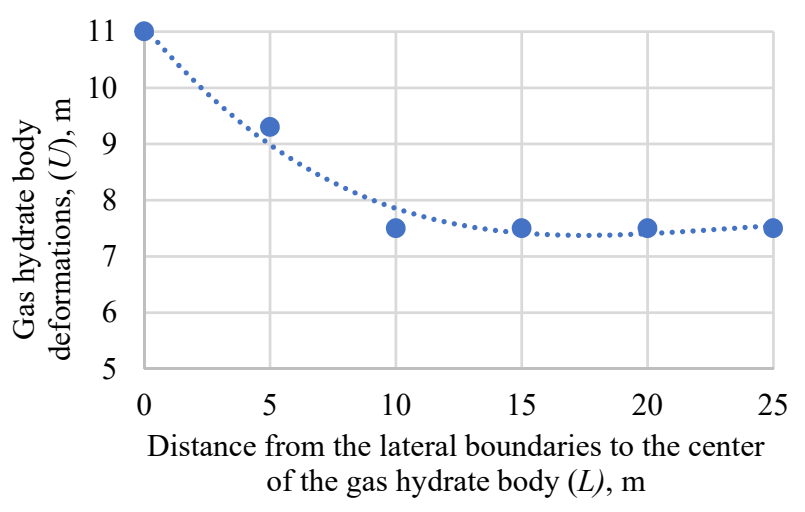

(c)

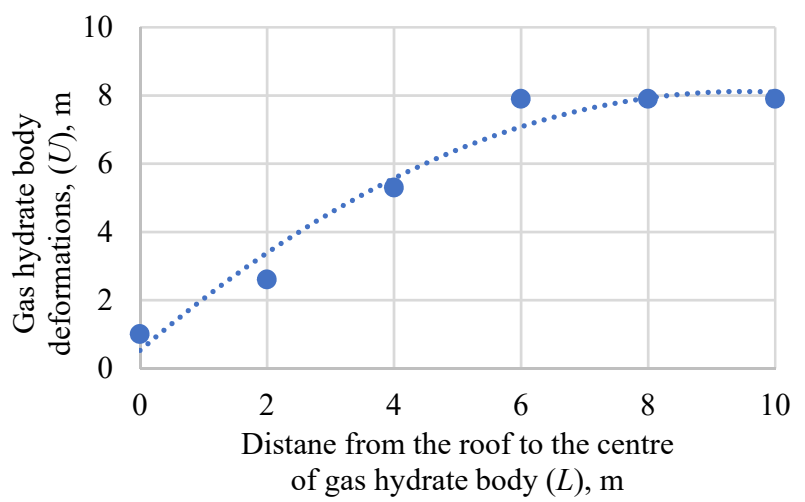

Figure 6. Results of the study of the gas hydrate body deformations: (a) the curve of general deformations; (b) dependence of deformation changes from the lateral boundaries to the well; (c) dependence of the deformation changes from the roof to the center of the gas hydrate body

\section{IMPROVEMENT OF THE TECHNOLOGICAL SCHEME FOR THE GAS HYDRATE DEPOSITS DEVELOPMENT IN THE BLACK SEA}

For the development of a gas hydrate deposit, a combined approach should be effective, which includes the temperature effect and the effect of the pressure by the activating agent on the gas hydrate deposit, but there are no technological schemes for the development of gas hydrate deposit based on this approach. Such a technological scheme based on the combined approach of methane gas extraction from marine gas hydrate deposits is proposed and patented by the authors of the article (Bondarenko, Prokopenko, Sai, Svietkina, \& Maksymova, 2018), taking into account the results of modeling by the finite element method.

In order to prepare the deposit, it is necessary to determine the contours of the developed deposit, taking into account the mining-geological and thermobaric conditions of its occurrence, as well as to establish temperature and depth ranges for further dissociation process control.

This method is applicable to the conditions of the Crimean gas hydrate deposit in the Black Sea. The recommended technological scheme for the development of a gas hydrate body (Figs. 7, 8) is as follows. The implementation of all drilling and extraction works is carried out from the floating platform to achieve the mobility of the installation, the minimum number of platforms is 3 units, the maximum is limited to the number of required wells.

Drilling involves conducting a central injection well, through which a directed drilling with a fan-like arrangement of horizontal branches relative to the central well with the help of $3 \mathrm{D}$ controlled rotating system is performed to increase the area of the activating agent effect and expand the dissociation front.

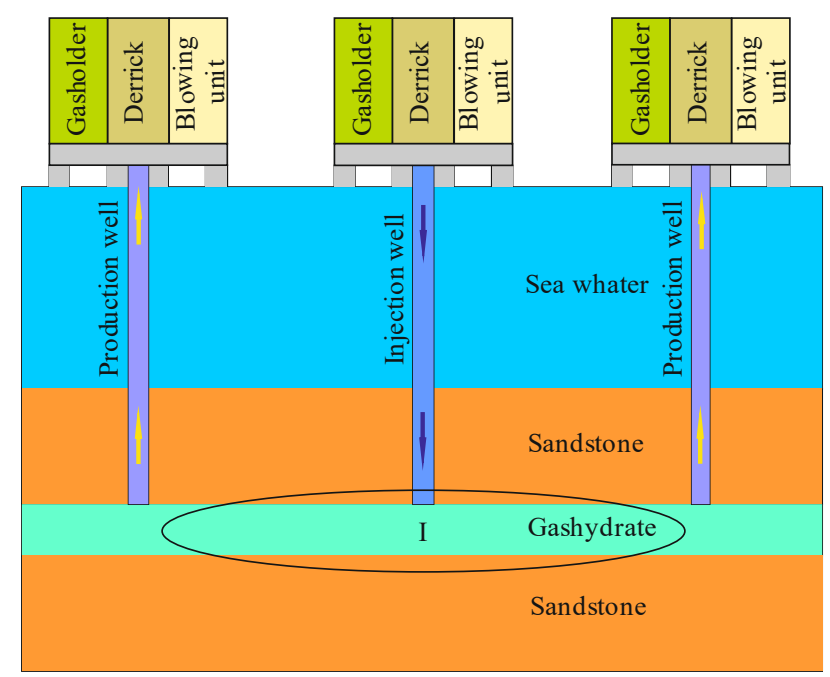

Figure 7. The recommended technological scheme for development of the considered gas hydrate deposit

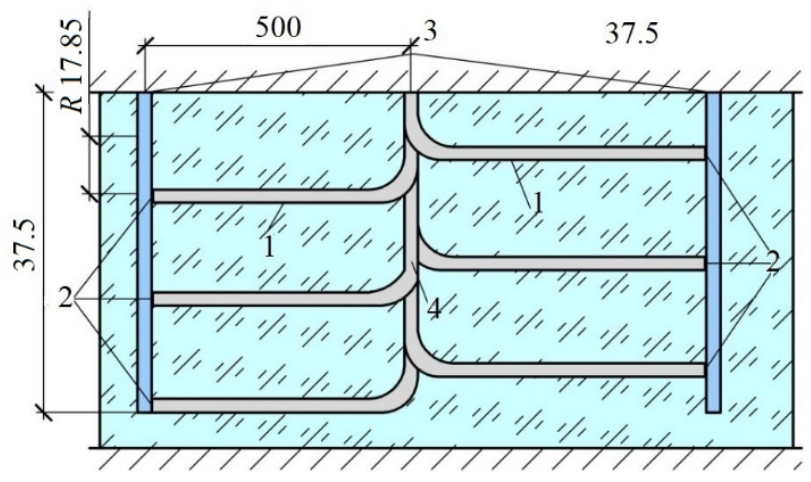

Figure 8. The layout of the closed hydraulic system

The process is carried out as follows. The central injection well 4 is drilled, from which the directional horizontal drilling is carried out by a fan-like way along the entire thickness of the gas hydrate body. Next, along the 
horizontal modules end zone 1 , the production wells 3 are drilled. After that the linkage is performed between the injection well 1 and the production wells 3 , and a unified hydraulic system of wells is formed, which allows to increase the controllability of the dissociation process and increase the productivity of gas extraction. Then, one-way high-pressure valves are installed at linkage locations to control the decomposition process of hydrates using the pressure parameter.

The warm sea water with a temperature of $+22^{\circ} \mathrm{C}$ from the surface layers under a pressure of $8 \mathrm{MPa}$, exceeding the existing pressure in the deposit, is pumped into the horizontal modules 1 . Due to the fact that in the gas hydrate body the initial pressure is $7 \mathrm{MPa}$, cracks are formed, which allow to increase the surface of the activating agent effect and promotes better release of the gas.

Due to the thermal effect of water and changes in pressure in the gas hydrate body, it breaks down and releases gas. In the process, high pressure valves 2 are activated, which allows to rapidly reduce the pressure in the dissociation zone and increase the rate of decomposition of hydrates by reducing the pressure to a point lower than that of the gas hydrate body. The released gas, along the vertical production wells 3 , enters the floating platform, where it is collected and sent to the gas storage.

Further, the pressure in the deposit is normalized due to the fact that the water, together with gas, was removed by means of the pressure difference from the production vertical wells 3 . The valves 2 are closed again and the operation is repeated.

This scheme of development is significantly different from those existing today. The main difference is that the combined system of effect on the gas hydrate body is used, with the change of the basic equilibrium parameters - temperature and pressure. Also, in the method proposed by the authors, there is a closed hydraulic system that minimizes the effect of gas and activating agent on the ambient medium, and the regulating one-way high pressure valves allow to control the dissociation process.

\section{CONCLUSIONS}

The gas hydrate deposits of the Black Sea are capable of ensuring Ukraine's energy independence in the near future as an alternative to natural gas. On the basis of scientific and technical analysis of the methods for the gas hydrate deposits development of the world's leading developed countries, for the Black Sea conditions the technological scheme for gas methane production from gas hydrates is proposed by a combined approach, combining the method of the gas hydrate body heating and its depressurization by increasing the pressure of the activating agent.

For research of thermodynamic and geomechanical processes during the decomposition of the gas hydrate body of the second geomorphological zone of the Black Sea, a spatial computer model was developed by the way of the proposed combined method with the help of the ANSYS software product with a set of characteristics and predetermined conditions close to the real ones.

As a result of modeling, it was found out that under the considered conditions the maximum thermal effect on the gas hydrate body with a temperature of $+22^{\circ} \mathrm{C}$ is observed at a distance of $18.7 \mathrm{~m}$ from the center of the well, and the minimum - at $+7^{\circ} \mathrm{C}$ at a distance of $25 \mathrm{~m}$. Thus, the temperature of the gas hydrates varies according to polynomial dependence with a distance to the well. The nature of pressure and deformation changes have been assessed, as well as the dependences have been determined of their change by the thickness and length of the gas hydrate body under the effect of the activating agent, which is fed under pressure exceeding the initial one. Thus, the maximum pressure is formed on the contact of the hydrate body and the enclosing rocks, and is $20 \mathrm{MPa}$, and the minimum pressure - in diameter $37.5 \mathrm{~m}$ around the well with a value of $3.3 \mathrm{MPa}$. Deformations are directed from the lateral boundaries to the center of the gas hydrate body at $11 \mathrm{~m}$ toward the productive dissociation zones, which in turn leads to the displacement of the gas hydrate into the center of the reaction, improving the quality of the decomposition process and allows mining of $87-91 \%$ gas hydrate volume, which is presented in the model.

An engineering solution was proposed for the gas hydrate deposit development in the form of a developed technological scheme, in which all drilling and extraction works are carried out from a floating platform to ensure the mobility of the installation. The minimum number of platforms is three, and the maximum is limited to the number of required wells. Drilling involves conducting a central injection well, through which a directed drilling with a fan-like arrangement of horizontal branches relative to the central well with the help of 3D controlled rotating system is performed to increase the area of the activating agent effect and expand the dissociation front.

\section{ACKNOWLEDGEMENTS}

The results of the current researches were obtained within the framework of the research works of GP-473 Development of scientific principles of phase transformations of technogenic and natural gas hydrates and creation of the newest technologies of their extraction" (State Registration No.0115U002294) and GP-487 "Scientific substantiation and development of energy saving and low waste technologies of hydrocarbon and mineral raw materials extraction" (State Registration No.0116U008041).

\section{REFERENCES}

97/01843 Thermodynamic Conditions for the Presence of Gas Hydrates in Sediments of the Black Sea. (1997). Fuel and Energy Abstracts, 38(3), 151. https://doi.org/10.1016/s0140-6701(97)87768-5

Bondarenko, V., Ganushevych, K., Sai, K., \& Tyshchenko, A. (2011). Development of Gas Hydrates in the Black Sea. Technical and Geoinformational Systems in Mining, 55-59. https://doi.org/10.1201/b11586-11

Bondarenko, V., Ganushevych, K., \& Sai, K. (2012). Substantiation of Technological Parameters of Methane Extraction from the Black Sea Gas Hydrate. In Materiaty Konferencyjne "Szkoła Eksploatacji Podziemnej” (pp. 20-24). Krakow, Poland: AGH University of Science and Technology.

Bondarenko, V., Symanovych, G., \& Koval, O. (2012). The Mechanism of Over-Coal Thin-Layered Massif Deformation of Weak Rocks in a Longwall. Geomechanical Processes During Underground Mining, 41-44. https://doi.org/10.1201/b13157-8 
Bondarenko, V.I., Kharin, Ye.N., Antoshchenko, N.I., \& Gasyuk, R.L. (2013). Basic Scientific Positions of Forecast of the Dynamics of Methane Release when Mining the Gas Bearing Coal Seams. Naukovyi Visnyk Natsionalnoho Hirnychoho Universytetu, (5), 24-30.

Bondarenko, V., Maksymova, E., Ganushevych, K., \& Sai, K. (2013). Gas Hydrate Deposits of the Black Sea's Trough: Currency and Features of Development. In Materiaty Konferencyjne “Szkoła Eksploatacji Podziemnej” (pp. 66-69). Krakow, Poland: AGH University of Science and Technology.

Bondarenko, V., Maksymova, E., Ganushevych, K., Sai, K., \& Illiashov, M. (2013). Scientific Bases of Methods and Technologies of Gas Hydrates Deposits Underground Mining. In World Mining Congress. Montreal, Quebec, Canada.

Bondarenko, V., Lozynskyi, V., Sai, K., \& Anikushyna, K. (2015). An Overview and Prospectives of Practical Application of the Biomass Gasification Technology in Ukraine. New Developments in Mining Engineering 2015: Theoretical and Practical Solutions of Mineral Resources Mining, 27-32. https://doi.org/10.1201/b19901-6

Bondarenko, V., Svietkina, O., \& Sai, K. (2017). Study of the Formation Mechanism of Gas Hydrates of Methane in the Presence of Surface-Active Substances. Eastern-European Journal of Enterprise Technologies, 5(6(89)), 48-55. https://doi.org/10.15587/1729-4061.2017.112313

Bondarenko, V.I., Prokopenko, K.M., Sai, K.S., Svietkina, O.Yu., \& Maksymova, E.O. (2018). Sposib vydobutku hazu $z$ morskykh hazohidrativ. Patent No.123576, Ukraina.

Boswell, R. (2009). Is Gas Hydrate Energy Within Reach? Science, 325(5943), 957-958. https://doi.org/10.1126/science.1175074

Carroll, J. (2014). Natural Gas Hydrates: A Guide for Engineers. Oxford, United Kingdom: Elsevier.

Chernov, A.A., Pil'nik, A.A., Elistratov, D.S., Mezentsev, I.V., Meleshkin, A.V., Bartashevich, M.V., \& Vlasenko, M.G. (2017). New Hydrate Formation Methods in a Liquid-Gas Medium. Scientific Reports, (7), 40809. https://doi.org/10.29202/phil-cosm/20/4

Demirbas, A. (2009). Methane from Gas Hydrates in the Black Sea. Energy Sources, Part A: Recovery, Utilization, and Environmental Effects, 32(2), 165-171.

https://doi.org/10.1080/15567030802463885

Dychkovskyi, R.O., $\quad$ Lozynskyi, V.H., $\quad$ Saik, P.B., $\quad$ Petlovanyi, M.V., Malanchuk, Ye.Z., \& Malanchuk, Z.R. (2018). Modeling of the Disjunctive Geological Fault Influence on the Exploitation Wells Stability During Underground Coal Gasification. Archives of Civil and Mechanical Engineering, 18(4), 1183-1197.

https://doi.org/10.1016/j.acme.2018.01.012

Ersland, G., \& Graue, A. (2010). Natural Gas Hydrates. Bergen, Norway: University of Bergen. https://doi.org/10.5772/9838

Ganushevych, K., \& Sai, K. (2013). Development of Gas Hydrate Reservoir in the Black Sea. Young Petro, (8), 45-50.

Ganushevych, K., Sai, K., \& Korotkova, A. (2014). Creation of Gas Hydrates from Mine Methane. Progressive Technologies of Coal, Coalbed Methane, and Ores Mining, 505-509. https://doi.org/10.1201/b17547-85

Gas Hydrates in the Black Sea Basin. (1990). Deep Sea Research Part B. Oceanographic Literature Review, 37(12), 1115. https://doi.org/10.1016/s0198-0254(06)80411-5

JOGMEC/NRCan/Aurora. (2018). Mallik Gas Hydrate Production Research Program. [online]. Available at: http://mallik.nwtresearch.com/index-2.html

Kimoto, S., Oka, F., Fushita, T., \& Fujiwaki, M. (2007). A ChemoThermo-Mechanically Coupled Numerical Simulation of the Subsurface Ground Deformations due to Methane Hydrate Dissociation. Computers and Geotechnics, 34(4), 216-228. https://doi.org/10.1016/j.compgeo.2007.02.006
Kobolev, V. (2017). Structural, Tectonic and Fluid-Dynamic Aspects of Deep Degassing of the Black Sea Megatrench. Mining of Mineral Deposits, 11(1), 31-49. https://doi.org/10.15407/mining11.01.031

Kollett, T.S., L'yuis R., \& Uchida, T. (2001). Rastushchiy interes k gazovym gidratam. Neftegazovoe Obozrenie, (Osen'), 38-53.

Korsakov, O.D., Byakov, Y.A., \& Stupak, S.N. (1989). Gas hydrates in the Black Sea Basin. International Geology Review, 31(12), 1251-1257.

https://doi.org/10.1080/00206818909465977

Krevelen, D.W., \& Nijenhuis, K. (2009). Properties of Polymers. New York, United States: Elsevier.

Kvenvolden, K.A. (1993). Gas Hydrates - Geological Perspective and Global Change. Reviews of Geophysics, 31(2), 173-187. https://doi.org/10.1029/93rg00268

Lan, S.Z., Hou, Y.B., \& Fan, P.F. (2015). Numerical Analysis on the Failure Mode of Stage Backfill Stope due to Mining Disturbance. Advanced Materials Research, (1089), 239-243. https://doi.org/10.4028/www.scientific.net/amr.1089.239

Lozynskyi, V., Saik, P., Petlovanyi, M., Sai, K., \& Malanchuk, Y. (2018). Analytical Research of the Stress-Deformed State in the Rock Massif around Faulting. International Journal of Engineering Research in Africa, (35), 77-88. https://doi.org/10.4028/www.scientific.net/jera.35.77

Makogon, Y. (1997). Hydrates of Hydrocarbons. Tulsa, Oklahoma, United States: Pennwell Books.

Makogon, Y.F., Holditch, S.A., \& Makogon, T.Y. (2007). Natural Gas Hydrates - A Potential Energy Source for the 21st Century. Journal of Petroleum Science and Engineering, 56(1-3), 14-31. https://doi.org/10.1016/j.petrol.2005.10.009

Makogon, Y.F. (2010a). Natural Gas Hydrates - A Promising Source of Energy. Journal of Natural Gas Science and Engineering, 2(1), 49-59. https://doi.org/10.1016/j.jngse.2009.12.004

Makogon, Yu.F. (2010b). Gazogidraty. Istoriya izucheniya i perspektivy osvoeniya. Geologiya i Poleznye Iskopaemye Mirovogo Okeana, (2), 5-21.

Maksymova, E. (2015). Methodological Approach to the Development of Gas Hydrate Deposits. New Developments in Mining Engineering 2015: Theoretical and Practical Solutions of Mineral Resources Mining, 129-132. https://doi.org/10.1201/b19901-24

Melnikov, V., \& Gennadinik, V. (2018). Cryodiversity: The World of Cold on the Earth and in the Solar System. Philosophy and Cosmology, (20), 43-54. https://doi.org/10.29202/phil-cosm/20/4

MH21 Research Consortium. (2018). Research Consortium for Methane Hydrate Resources in Japan. [online]. Available at: http://www.mh21 japan.gr.jp/english/

Mykhailov, V. (2016). Prospection and Estimation of Unconventional Hydrocarbon Deposits in Ukraine. Visnyk of Taras Shevchenko National University of Kyiv. Geology, 2(73), 38-45. https://doi.org/10.17721/1728-2713.73.06

National Energy Technology Laboratory. (2017). Methane Hydrate. Science and Technology: A 2017 Update. Research Report. Washington, United States: U.S. Department of Energy.

Pedchenko, M., \& Pedchenko, L. (2017). Analysis of Gas Hydrate Deposits Development by Applying Elements of Hydraulic Borehole Mining Technology. Mining of Mineral Deposits, 11(2), 52-58. https://doi.org/10.15407/mining11.02.052

Petlovanyi, M.V., Lozynskyi, V.H., Saik, P.B., \& Sai, K.S. (2018). Modern Experience of Low-Coal Seams Underground Mining in Ukraine. International Journal of Mining Science and Technology. Article in press. https://doi.org/10.1016/j.ijmst.2018.05.014 
Permyakov, M.E. (2010). Effektivnaya teploprovodnost' gidratosoderzhashchikh obraztsov po rezul'tatam laboratornykh izmereniy pri razlichnykh $R$-T-usloviyakh. PhD. Novosibirsk: Institut neftegazovoy geologii i geofiziki im. A.A. Trofimuka Sibirskogo otdeleniya RAN.

Processes for Methane Production from Gas Hydrates. (2010). Green Energy and Technology, 161-181. https://doi.org/10.1007/978-1-84882-872-8 5

Rogers, R. (2015). Producing Methane from Offshore Hydrates. Offshore Gas Hydrates, 101-133. https://doi.org/10.1016/b978-0-12-802319-8.00004-8

Shnyukov, E.F. (2013). Mud Volcanoes of the Black Sea as a Prospecting Indicator of Methane Gas Hydrates. Lithology and Mineral Resources, 48(2), 114-121. https://doi.org/10.1134/s0024490213010045

Swaranjit Singh, A.A. (2015). Techniques for Exploitation of Gas Hydrate (Clathrates) an Untapped Resource of Methane Gas. Journal of Microbial \& Biochemical Technology, 07(02), 108-111.

https://doi.org/10.4172/1948-5948.1000190

Taheri, Z., Shabani, M.R., Nazari, K., \& Mehdizaheh, A. (2014). Natural Gas Transportation and Storage by Hydrate Technology: Iran Case Study. Journal of Natural Gas Science and Engineering, (21), 846-849.

https://doi.org/10.1016/j.jngse.2014.09.026
Thakur, N.K., \& Rajput, S. (2010). Gas Hydrates. Exploration of Gas Hydrates, 49-72. https://doi.org/10.1007/978-3-642-14234-5 3

Vilner, Ya.M., Kovalev, Ya.T., \& Nekrasov, B.B. (1976). Spravochnoe posobie po gidravlike, gidromashinam $i$ gidroprivodam. Minsk: Vyisheyshaya shkola.

Waite, W.F., Stern, L.A., Kirby, S.H., Winters, W.J., \& Mason, D.H. (2007). Simultaneous Determination of Thermal Conductivity, Thermal Diffusivity and Specific Heat in Methane Hydrate. Geophysical Journal International, 169(2), 767-774. https://doi.org/10.1111/j.1365-246x.2007.03382.x

Wang, X., \& Economides, M.J. (2011). Natural Gas Hydrates as an Energy Source - Revisited. In International Petroleum Technology Conference. Bangkok, Thailand: Bangkok Convention Centre Central World. https://doi.org/10.2523/IPTC-14211-ms

Zhao, J., Yu, T., Song, Y., Liu, D., Liu, W., Liu, Y., \& Li, Y. (2013). Numerical Simulation of Gas Production from Hydrate Deposits Using a Single Vertical Well by Depressurization in the Qilian Mountain permafrost, Qinghai-Tibet Plateau, China. Energy, (52), 308-319.

https://doi.org/10.1016/j.energy.2013.01.066

\section{ДОСЛІДЖЕННЯ ТЕРМОДИНАМІЧНИХ І ГЕОМЕХАНІЧНИХ ПРОЦЕСІВ ПРИ РОЗРОБЦІ ГАЗОГІДРАТНИХ ПОКЛАДІВ В УМОВАХ ЧОРНОГО МОРЯ}

\section{В. Бондаренко, К. Сай, К. Прокопенко, Д. Журавльов}

Мета. Дослідження термодинамічних і геомеханічних процесів, що протікають у газогідратному тілі при впливі активуючого агента (морської води з поверхневих шарів) в умовах Чорного моря шляхом математичного моделювання методом кінцевих елементів.

Методика. Моделювання термодинамічних і геомеханічних процесів виконано за допомогою програмного забезпечення ANSYS v17.0 з відповідністю кліматичних, гідрогеологічних та фізико-механічних властивостей елементів чисельної моделі у розглянутому газогідратному родовищі Чорного моря, які є аналогічними натурним. Термодинамічні процеси досліджувалися у розділі програми "Steady-State Thermal", а геомеханічні (напружено-деформований стан) - в “Static Structural”.

Результати. Розроблена просторова модель, що дозволяє моделювати термодинамічні та геомеханічні процеси у газогідратному тілі при впливі теплового агента. В результаті моделювання встановлено, що у розглянутих умовах температура в газогідратному тілі змінюється з відстанню від видобувної свердловини аналогічно в обидві сторони за поліноміальною залежністю, причому на відстані від свердловини 18.7 м температура стабільна і становить $+22^{\circ} \mathrm{C}$, а в інтервалі $18.7-24.9$ м - знижується у 3.1 рази і досягає значення $+7^{\circ} \mathrm{C}$. Виявлено, що деформації у газогідратному тілі при впливі активуючого агента, який подається під тиском, що перевищує початковий, спрямовані від бокових меж у центр газогідратного тіла у напрямі продуктивних зон дисоціації, що, в свою чергу, призводить до зміщення об'єму газогідрату в центр протікання реакції, покращуючи якість процесу розкладання і дозволяючи відпрацювати 87 - 91\% об'єму газогідрата, представленого в моделі.

Наукова новизна. Вперше для умов газогідратних родовищ Чорного моря проведена аналітична оцінка характеру поширення зони дисоціації від видобувної свердловини при впливі теплового агента та змін напружено-деформованого стану газогідратного тіла при його розкладанні, що дозволяє удосконалити технологію розробки газогідратних покладів у розглянутих умовах.

Практична значимість. Запропоновано технологічну схему розробки газогідратного тіла на основі комбінованого підходу до впливу активаторами (температурою та тиском), що усуває необхідність прогріву граничних ділянок покладу і збільшення кількості активуючого агента, що подається, та його температури, що, в свою чергу, веде до зниження ресурсо- й енерговитрат.

Ключові слова: газогідратний поклад, метод кінщевих елементів, програмний пакет ANSYS, зона дисоиіації, технологічна схема розробки

\section{ИССЛЕДОВАНИЕ ТЕРМОДИНАМИЧЕСКИХ И ГЕОМЕХАНИЧЕСКИЕ ПРОЦЕССОВ ПРИ РАЗРАБОТКЕ ГАЗОГИДРАТНЫХ ЗАЛЕЖЕЙ В УСЛОВИЯХ ЧЕРНОГО МОРЯ}

\section{В. Бондаренко, Е. Сай, К. Прокопенко, Д. Журавлёв}

Цель. Исследование термодинамических и геомеханических процессов, протекающих в газогидратном теле при воздействии активирующего агента (морской воды с поверхностных слоев) в условиях Черного моря посредством математического моделирования методом конечных элементов. 
Методика. Моделирование термодинамических и геомеханических процессов выполнено при помощи программного обеспечения ANSYS v17.0 с соответствием климатических, гидрогеологических и физико-механических свойств элементов численной модели в рассматриваемом газогидратном месторождении Черного моря, которые являются аналогичными натурным. Термодинамические процессы исследовались в разделе программы "SteadyState Thermal", а геомеханические (напряженно-деформированное состояние) - в "Static Structural".

Результаты. Разработана пространственная модель, позволяющая моделировать термодинамические и геомеханические процессы в газогидратном теле при воздействии теплового агента. В результате моделирования установлено, что в рассматриваемых условиях температура в газогидратном теле изменяется с расстоянием от добывающей скважины аналогично в обе стороны по полиномиальной зависимости, причем на расстоянии от скважины 18.7 м температура стабильна и составляет $+22^{\circ} \mathrm{C}$, а в интервале $18.7-24.9$ м - снижается в 3.1 раза и достигает значения $+7^{\circ} \mathrm{C}$. Выявлено, что деформации в газогидратном теле при воздействии активирующего агента, подаваемого под давлением, превышающее начальное, направлены от боковых границ в центр газогидратного тела в направлении продуктивных зон диссоциации, что, в свою очередь, приводит к смещению объема газогидрата в центр протекания реакции, улучшая качество процесса разложения и позволяя отработать 87 - 91\% объема газогидрата, представленного в модели.

Научная новизна. Впервые для условий газогидратных месторождений Черного моря проведена аналитическая оценка характера распространения зоны диссоциации от добывающей скважины при воздействии теплового агента и изменений напряженно-деформированного состояния газогидратного тела при его разложении, что позволяет усовершенствовать технологию разработки газогидратных залежей в рассматриваемых условиях.

Практическая значимость. Предложена технологическая схема разработки газогидратного тела на основании комбинированного подхода к воздействию активаторами (температурой и давлением), устраняющая необходимость прогрева граничных участков залежи и увеличения подаваемого количества активирующего агента и его температуры, что, в свою очередь, ведет к снижению ресурсо- и энергозатрат.

Ключевые слова: газогидратная залежь, метод конечных элементов, программный пакет ANSYS, зона диссочиации, технологическая схема разработки

\section{ARTICLE INFO}

Received: 14 December 2017

Accepted: 3 May 2018

Available online: 15 May 2018

\section{ABOUT AUTHORS}

Volodymyr Bondarenko, Doctor of Technical Sciences, Head of the Underground Mining Department, Dnipro University of Technology, 19 Yavornytskoho Ave., 49005, Dnipro, Ukraine. E-mail: v domna@yahoo.com

Kateryna Sai, Candidate of Technical Sciences, Assistant Professor of the Underground Mining Department, Dnipro University of Technology, 19 Yavornytskoho Ave., 49005, Dnipro, Ukraine. E-mail: kateryna.sai@gmail.com

Kostiantyn Prokopenko, PhD Student of the Underground Mining Department, Dnipro University of Technology, 19 Yavornytskoho Ave., 49005, Dnipro, Ukraine. E-mail: npakon2536@gmail.com

Dmytro Zhuravlov, Doctor of Law, First Deputy Director of the Scientific Research Institute of Public Law, 116 Kozatska St, 03118, Kyiv, Ukraine. E-mail: ndz0909@gmail.com 